УДК 811.161.2’276.6:622

\title{
ВІДОНІМНІ ДЕРИВАТИ В ТЕРМІНОЛОГІЇ ГІРНИЧОЇ СПРАВИ
}

\author{
Жанна Колоїз \\ Криворізький державний педагогічний університет \\ Kryvyi Rih State Pedagogical University \\ nр. Гагаріна, 54, Кривий Ріг, 50086, Україна \\ koloiz.zv@gmail.com
}

Колоїз Ж. Відонімні деривати в термінології гірничої справи

У статті досліджено апелятивні відонімні деривати, що функціонують у термінологічному корпусі гірничої справи, 3'ясовано їх дериваційногенетичні зв'язки. На прикладі найменувань гірських порід та мінералів простежено способи словотворення, виявлено найпродуктивніші форманти, проілюстровано ті чи ті фономорфологічні процеси, які супроводжують процес словотворення (чергування, усічення, інтерфіксація). Розглянуто особливості адаптації та кодифікації відонімних найменувань на українському грунті, їхню варіантність, зроблено спробу пояснити причини іiі появи. Акцентовано на непослідовності й суперечливості у продукуванні й написанні апелятивних відонімних дериватів, що подекуди відбувається усупереч із чинними нормами (орфоепічними, орфографічними, словотвірними і т. ін.) української мови. Виокремлено передусім варіантність, зумовлену написанням: латинських літер $g$ і $h$ українською мовою; відонімних дериватів, спродукованих на основі власних назв, що ілюструють подвоєння; онімного дериватора й апелятивного деривата, пов'язаного із так званим правилом “дев'ятки”; іншомовних букв і буквосполучень, використовуваних для позначення невластивих українській мові звуків тощо.

Ключові слова: гірнича термінологія, відонімний дериват, онімний дериватор, формант, суфікс, фономорфологічні процеси, правопис.

Колоиз Ж. Отонимные дериваты в терминологии горного дела

В статье исследуются апеллятивные отонимные дериваты, функционирующие в терминологическом корпусе горного дела, выясняется их деривационные и генетические отношения. На примере наименований горных пород и минералов прослеживаются способы словообразования, определяются самые продуктивные форманты, иллюстрируются те или иные фономорфологические процессы, которые сопровождают процесс словообразования (чередование, усечение, интерфиксация). Рассматриваются особенности адаптации и кодификации отонимных наименований в украинском языке, их вариантность, делается попытка объяснить причины ее 
появления. Акцентируется внимание на непоследовательности и противоречивости в продуцировании и написании апеллятивных отонимных дериватов, что иногда происходит вопреки действующим нормам (орфоэпическим, орфографическим, словообразовательным и т. д.) украинского языка. Комментируется прежде всего вариантность, связанная с написанием: латинских букв $g$ и $h$ украинским языком; отонимных дериватов, образованных на основе имен собственных, которые иллюстрируют удвоение; онимного дериватора и апеллятивного деривата, связанного с так называемым правилом “девятки”; иноязычных букв и буквосочетаний, используемых для обозначения несвойственных украинскому языку звуков и т. п.

Ключевые слова: горная терминология, отонимний дериват, онимний дериватор, формант, суффикс, фономорфологические процессы, правописание.

Koloiz Zh. Onym Derivatives in Mining Terminology

The paper investigates the appellative onym derivatives that function in the Mining terminology. It also focuses on the derivative-genetic connections. The nominations of rocks and minerals become the basis of tracing the methods of word formation (morphological and non-morphological). Furthermore these language units allow distinguishing the most productive formants, such as the suffixes -um, $-i m$, and -лim. Moreover this research studies the certain problems of the derivative base formation, its semantics and some of the phono-morphological processes, which accompany the process of word formation (alternation, truncation, interfixation). It is observed that the typical way for specific Mining term production is interfixation. It is defined as a morphological phenomenon, in which an asemantic gasket appears on a morphemic seam. Intermorphemic segments generally fulfill a formal function. Their task is to simplify the process of combining morphemes. The most commonly reduced language units are one-component finite segments, consisting of a vowel phoneme or phonemic combinations.

The paper reveals the peculiarities of adaptation and codification of distinctive Ukrainian nominations, their variability, as well as explains the reasons for its formation. The emphasis is laid on the inconsistency and contradictions in the production and spelling of appellative onym derivatives, which sometimes occurs contradicting the current principles of the Ukrainian language (orphoetic, spelling, word formation, etc.). Firstly, the variation of spelling the Latin letters $g$ and $h$ in the Ukrainian language is distinguished. Secondly onym derivatives that are produced on the basis of their own nominations and illustrate doubling are analyzed. Thirdly onym derivatives and appellate derivatives associated with the so-called "nine" rule are investigated. The usage of foreign language letters and letter combinations denoting sounds, which are not specific to the Ukrainian language are represented.

The lack of research studying the problems of standardization and unification of Mining terminology leads to the emergence of so-called double standards. Moreover, such double standards are represented by lexicographic works and give the right to choose sometimes correct substitutes.

Key words: mining terminology, onym derivate, onym derivative, formant, suffix, phonomorphological processes, spelling. 


\section{Постановка проблеми та її зв'язок із важливими} науковими завданнями. На сучасному етапі розвитку вітчизняної лінгвістичної науки не виникає жодних сумнівів, що термінознавство $є$ однією з провідних іiі царин, розбудова якої зумовлена як науково-технічним прогресом, так і національним відродженням України. Термінологія “стала невід’ємним i важливим складником лексичної мовної системи”, невіддільною частиною науково-дослідницької діяльності, "що засвідчує досягнення кожної окремої ділянки знання на певному етапі іiі розвитку" [Tomilenko / Томіленко 2015 : 5].

Упродовж кількох десятиліть українські термінологи активно розробляють як загальні термінологічні поняття, так і часткові, ті, що пов'язують із відповідною термінологічною підсистемою (С. Булик-Верхола, М. Вакуленко, Л. Веклинець, I. Волкова, В. Захарчин, О. Карабута, Л. Козак, М. Костенко, I. Кочан, 3. Куньч, Т. Лепеха, О. Литвин, С. Локайчук, Л. Малевич, Г. Наконечна, Н. Непийвода, Н. Овчаренко, Г. Онуфрієнко, В. Пілецький. М. Процик, Г. Ракшанова, Н. Руколянська Л. Симоненко, М. Сташко, Л. Філюк, Д. Шапран, Н Яценко та ін.). На сьогодні, за підрахунками лінгвістів, уже систематизовано й проаналізовано матеріали понад сто терміносистем [Tomilenko / Томіленко 2015:23]. Численні термінознавчі здобутки сприяли розбудові вітчизняної термінознавчої думки, окреслили перспективи подальших напрацювань. Дослідження тієї чи тієї фахової лексики стало “важливою науково-технічною проблемою, від успішного розв’язання якої залежить ефективність міжнародних контактів держави та іï місце у світовому розподілі праці" [Vakulenko / Вакуленко 2015 : 10].

Не залишилася поза увагою науковців і так звана гірнича термінологія, або термінологія гірничої справи (В. Альохін, О. Барабанова, В. Білецький, П. Василенко, О. Колган, О. Колоколов, Т. Котишева, В. Мирний, Б. Панов, І. Сокол, I. Шелудько та ін.). Одні з них працюють над унормуванням та стандартизацією фахової лексики зазначеної царини, другі з'ясовують іiі семантичні особливості, витлумачують значення, треті - досліджують дериваційну структуру, окреслюють шляхи 
та способи творення гірничих найменувань на різних етапах розвитку терміносистеми і т. ін. Як зауважують дослідники, “в основному термінотворення й кодифікація номенклатури цієї галузі відбувалися в 20-30-ті рр. минулого століття” [Sokol / Сокол 2013 : 53], як “функціональна підсистема національної мови українська гірнича термінологія пройшла довгий і досить складний шлях становлення, про що свідчать численні пам'ятки писемності, історичні документи та лексикографічні праці”, особливо значного розвитку “набула в 90-і pp. ХX ст. - час становлення державності в Україні” [Kolhan / Колган 2009 : 13]. Однак говорити про те, що теорія гірничого термінознавства на сьогодні $\epsilon$ викінченою, вочевидь, зарано. Адже в термінологічному активі потужного гірничо-видобувного та гірничо-переробного секторів ще чимало проблемних, остаточно не розв'язаних питань.

Аналіз останніх досліджень та публікацій. Термінологічна система гірничої справи має самобутній характер та глибоку історію, що не могло залишитися поза увагою лінгвістів. Це сприяло появі цілої низки наукових праць теоретичного та прикладного характеру [Sokol / Сокол 2013 : 52-57]. Як вітчизняні, так і зарубіжні науковці досліджують гірничу терміносистему здебільшого 3 позицій синхронії, обгрунтовуючи теоретичні засади ії вироблення (Т. Богатирьова, М. Бонеліс, С. Левіна, І. Лях, С. Решетняк, А. Рудакова, О. Сичова, Н. Устинова, Р. Фролов та ін.). Зроблено загалом успішну спробу з'ясувати лексико-семантичні основи й української термінології гірничої справи, визначити шляхи та способи творення гірничих найменувань на різних етапах розвитку терміносистеми. У 2009 році в науковому обігу з'явилася комплексна дисертаційна праця, об'єктом дослідження якої стала українська гірнича термінологія, зокрема iii семантична та словотвірна структура [Kolhan / Колган 2009]. Щоправда, деякі з питань чи то розглянуті лише принагідно, чи то продовжують залишатися дискусійними. Це стосується як теоретичних, так і прикладних аспектів дослідження тих чи тих понять в українському гірничому термінознавстві. 3-поміж усього розмаїття проблемних моментів вирізняється 
уналежнення окремих термінів до гірничої (чи то суміжної 3 нею) царини (пор.: “гірнича наука вивчає умови залягання родовищ корисних копалин і фізичні явища, що відбуваються в товщі гірських порід при створенні гірничих виробок, способи видобування i збагачування корисних копалин, організацію виробництва, яка зумовлює безпечну й економічну розробку родовищ”, передбачає “дослідження в галузі розкривання i систем розробки родовищ, гірничої геомеханіки, маркшейдерії, боротьби з рудниковим газом і пилом, гірничої економографії тощо" [Tlumachnyi hirnychyi slovnyk / Тлумачний гірничий словник 1998 : 3]), процеси номінації спеціальних понять, спосіб продукування похідних дериватів, установлення дериваційної бази, мотиваційних відношень і т. ін.

Мета запропонованої статті - дослідження апелятивних відонімних дериватів, що функціонують у термінологічному корпусі гірничої справи, крізь призму дериваційних особливостей, чинного правопису, нормалізації та стандартизації. Задля досягнення мети зроблено акцент на проблемах сучасної гірничої термінології загалом та дискусійних моментах у продукуванні відонімних дериватів зокрема, їхніх зв'язках із дериваційною базою.

Виклад основного матеріалу. Процес формування української термінології, як відомо, розпочався фактично після закінчення громадянської війни: 31921 року у складі ВУАН почав функціонувати Інститут української наукової мови, завдання якого полягало в укладанні термінологічних словників, у нормалізації української наукової термінології. Поодинокі спроби розбудови української термінології засвідчені ще в XIX ст.: у 1861 році в журналі “Основа" з'явилася стаття Миколи Левченка “Замітки про русинську термінологію”, де він пропонує створювати наукові терміни в дусі народної мови, аби ïx міг сприймати сам народ, водночас виступаючи проти запозичень у термінології. До статті було додано словничок, що містить не більше двох десятків слів, створених самим автором, зокрема й на позначення тих понять, що активно функціонують у гірничій справі: фахову лексему автомат пропонувалося замінити терміном саморух, механіка - силодійня, натрій - 
солещь, алюміній - глинець, азот - душець, хлор - зеленець, басейн - котловина, канал - провод, ииліндр - валець, елемент первина, метал - ковань, мінерал - нерост, крушець тощо [Levchenko / Левченко 1861].

Початок формування термінології власне гірничої справи припадає на 1924 рік й пов'язується 3 систематичною термінологічною працею в Гірничій секції, яка опрацювала й відредагувала близько тисячі основних термінів галузі, що згодом прислужилися при впорядкуванні словника загальнотехнічної термінології. У 1931 році у Харкові побачив світ і вузькоспеціальний “Словник гірничої термінології”, де в поглядах на засади добору термінологічної лексики засвідчена й так звана пуристична тенденція: більш звичні, але неукраїнські терміни рекомендували замінити на спродуковані на українському грунті, однак малозрозумілі не лише спеціалістам, а й широкому загалу: благородний витлумачувався через лексему добророднии; вентилятор - вітрогон; врубмашина -зарубувалка; завод - виробня; качання насосом смоковання; зарубка вертикальна - заруб сторчовий. Деякі 3 найменувань отримали по три i більше синонімічні відповідники: наприклад, бобина (для канату) - шпуля, навій, мітниня; канат - линва, мотуз, лина, корда, мотов'яз, гужва; пласт - верства, шар, скиба, ряд, пластів'я, штих, верствовиця. Чимало пропонованих гірничих термінів запозичувалися 3 російської мови шляхом калькування: отметчик - значій; пьль инертная - пил байдужий; устье горло, гирло, горловище; шест - тичина, жердина; ямщик кидальник, ямкар.

Пошуки україномовного терміна активізувалися особливо тоді, коли для означення того чи того поняття використовувався незрозумілий рідковживаний іншомовний: термін anoфiзa (рос. жилы) (< грец. apophysis - відросток) зі значенням “відгалуження магматичного тіла в сусідні гірські породи” став поступово витіснятися терміном паросток; термін конгломерат (< лат. conglomerare - нагромаджувати, ущільнюватися) потрактовували здебільшого як “зцементована гірська порода, що складається здебільшого з гальки та домішки піску, гравію”;

(с) Ж. Колоїз, 2019. 
iз тим же значенням використовували i фахову лексику на зразок зліпинець, зліпняк, зліпище.

Подекуди однослівні запозичені терміни отримували кількаслівні відповідники: як синонімічні використовувалися маркше́йдер (< нім. Markscheider < Mark - межа, scheider відокремлювати) - гірничий інженер; для означення “галузі гірничої науки, яка здійснює просторово-геометричні вимірювання в надрах Землі i на відповідних ділянках іii поверхні” пропонувалося кілька термінів: маркшейдерія, маркшайдерство, і навіть двокомпонентний - мірництво гірниче. Іноді навпаки: двокомпонентні пропонувалося замінити однокомпонентними: рос. мастер ламповый українською мовою передавалося як лямпівник, ламповий; рос. буровые скважины свердловини.

Термінологічні словосполучення в термінології гірничої справи - явище непоодиноке (наприклад, наявні близько сорока терміносполучень зі стрижневим словом шахта, що поширюється здебільшого прикметником: буровугільна, вентиляційна, водовідлвна, видавальна, витяжна, похила, негазова; аналогічна ситуація й зі словом штанга - бурова, ведуча, обертова, вибивна, гнучка, ловильна, напрямна, насосна, відбійна і т. ін.).

Сьогодні більш грунтовного аналізу потребують зв'язки спеціальної лексики гірничої справи всередині системи та іiі відношень зі словами загальнолітературної мови. Недостатньо опрацьованими є й питання нормалізації й уніфікації гірничої термінології, що призводить до появи так званих подвійних стандартів (у гірничій термінології паралельно функціонують липкість = клейкість; морозостійкість гірських порід = морозотривкість гірських порід; мулисті потоки = каламутні потоки; навал висадженої гірничої маси = розвал висадженої гірничої маси; насосний агрегат заглибний = насосний агрегат занурений; оголення гірських порід = відслонення гірських порід). Причому такі подвійні стандарти репрезентовані й лексикографічними працями, які дають право вибору, що подекуди є не завжди правильним (розкіска / розкосина; башмак / черевик колони насосно-компресорних труб; падіння пласта / 
шару/ жили/ поверхні розриву; перекинуте / перевернуте залягання; центр ствола / стовбура шахти). Можна відзначити момент, що стосується не тільки професійної термінології, а й загальномовного питання щодо вживання / невживання термінів-дієприкметників: швидкодіючий чи той, який швидко діє; швидкорізальний, швидкоріжучий чи той, який швидко ріже; швидкотвердіючий, швидкотверднучий чи той, який швидко твердіє (твердне). Це питання залишається й досі дискусійним.

3 лінгвістичних позицій заслуговує на увагу й виявлення генетичних особливостей термінів гірничої справи, а також адаптація іншомовних запозичень на українському грунті. Так, наприклад, фонетично-граматична адаптація запозичень 3 німецької мови (абзетиер < Absetzer; маркшейдер < Markscheider; шахma <Schacht; штрек < Streck; шурф <Schurf; шнек $<$ Schneck) суттєво відрізняються від, скажімо, запозичень iз грецької (авгіт, автоген, аероліт, азбест), латинської (абляція, абсорбер, агрегачія, альбіт, альдегіди), французької (азурит, алонж, алуніт, амальгама). До того ж деякі номени були запозичені опосередкованим шляхом. Скрупульозного дослідження потребує і вплив запозичених терміноелементів на формування національної терміносистеми (аквамарин, акваметрія, акванал, де аква ... < лат. аqиа - вода; акваметрія методи визначення кількості води в різних речовинах; акванал вибухова речовина, що містить воду, до складу якої входить дисперсний алюміній). Генетичний опис мав би обов'язково репрезентуватися у спеціальних лексикографічних працях.

На окрему увагу заслуговує група так званих відонімних термінів, наприклад для найменування гірських порід, як-от: монцен $+i m \leftarrow$ Монцоні “найменування гори в Альпах"; ciєн+im $\leftarrow$ Сієна "найменування міста в італійському регіоні Тоскана"; бокс $+u m \leftarrow$ ле'Бо “найменування місцевості на півдні Франціі”; кімберл+im $\longleftarrow$ Кімберлі "найменування міста в ПівденноАфриканській Республіці"; ліпар+um $\leftarrow$ Ліпарі “один із вулканічних островів у Тірренському морі на північ від Сицилії; штренг+im $\longleftarrow$ Штренг “прізвище німецького мінералога Й. А. Штренга"; итрунич+um $\leftarrow$ Штрунц “прізвище 
німецького мінералога Г. Штрунца" і т. ін. чи то для номінації хімічних елементів: $m о р+i и ̆ \leftarrow$ Тор “ім'я бога-громовержця в давньоскандинавській міфології”; иер +ій $\leftarrow$ Церера “найменування найближчої до Сонця й найменшої серед відомих карликових планет Сонячної системи”; тантал Ł Тантал “ім'я героя давньогрецької міфології”; ітерб+ій $\leftarrow$ Ітербю “найменування селища в Швеції”; каліфорній Ł Каліфорнія “найменування штату у США”; палад+iй $\longleftarrow$ Паллада “ім'я в давньогрецькій міфології; найменування астероїда"; $p e н+i \check{u} \leftarrow$ Рейн “найменування річки”; сканд+iй $\leftarrow$ Скандинавія “найменування регіону в Північній Європі”; терб+ій $\leftarrow$ Ітербю “найменування селища в Швеції” тощо. Ідеться не лише про той чи той спосіб продукування [Barabanova / Барабанова 2010], форманти, використовувані у процесі деривації, але й про відповідні проблеми встановлення дериваційної бази, іï семантичних особливостей, виявлення тих фономорфологічних процесів, які супроводжують процес словотворення. Важливою залишається й проблема стабілізації та нормалізації відповідної термінології гірничої справи.

Варто віддати належне науковцям, об'єктом вивчення яких стали чи то терміни гірничої справи загалом [Kolhan / Колган 2009], чи то однісї з їі сфер, скажімо, гірничомінералогічної [Ovcharenko / Овчаренко 1996]. Для реалізації мети тієї чи тієї дисертаційної праці вони сформулювали i в основному успішно розв'язали окреслені завдання. Однак 3-поміж усього розмаїття розв'язуваних проблем відонімним гірничим (мінералогічним [Panko / Панько 1994 : 71]) дериватам усе ж таки приділено недостатньо уваги. Щоправда, протягом останнього десятиліття у вітчизняному термінознавстві 3'явилося чимало праць, де одним із ключових понять $є$ термін епонім, який витлумачують чи то як власну назву, що стала “основою для творення мовного знака з новим значенням”, чи то як “термін, утворений від власних імен” [Dziuba / Дзюба 2010 : 55]. Такі праці актуалізують переважно медичну (Б. Банул, Н. Назарчук, Н. Решетилова, Г. Сингаївська, Л. Стегницька, О. Харик та ін.), рідше анатомічну (В. Лисенко), валеологічну (Л. Удовенко), спортивну (Р. Коваль, О. Романчук, К. Якимів), 
астрономічну (А. Соломахін) епонімію. Подекуди дослідники акцентують увагу на семантичних особливостях дериваційної бази, як-от: прізвищеві та відпрізвищеві терміни в мові української фізичної термінної системи [Mykulchyk / Микульчик 2016]. У будь-якому разі впадає в око те, що аналізові піддають здебільшого словосполучення, одним із компонентів яких $\epsilon$ власна назва, як-от: симптом Брунаті, симптом Левассера, синдром Штофера, синдром Мондора, ефект Барнетта, ефект Казимира, квантовий ефект Хола, мереорит Альєнде, телескоп Шмідта, телескоп Максутова, серія Бальмера, петля Барнарда, комета Шмідта, комета Галлея, меридіан Керрінгтона, критерій Джинса, шкала Фаренгейта тощо. Пор. назви мінералів: мінерал Гентце, мінерал Дюррфельда.

Термінологія гірничої справи ілюструє низку найменувань-апелятивів, утворених на основі тих чи тих онімів за допомогою суфіксальних формантів, переважно суфіксів -ит (бранер+um $\leftarrow$ Браннер “прізвище американського геолога Дж. Браннера"; брус+um $\leftarrow$ Брус “прізвище американського мінералога А. Бруса"; кізер $+u m \leftarrow$ Кізер "прізвище німецького вченого, представника натурфілософського напряму в медицині Д. Г. фон Кізера"; пруст + um $\leftarrow$ Пруст “прізвище французького хіміка Ж. Пруста"; борн $+i m \leftarrow$ Борн “прізвище австрійського мінералога та металурга I. фон Борна”тощо), -im (брук+im $\leftarrow$ Брук “прізвище англійського мінералога Г.-Дж. Брука"; бурнон+im $\longleftarrow$ Бурнон “прізвище французького мінералога Дж. Бурнона"; епсом $+i m \leftarrow$ Епсом “назва мінеральних джерел в Англію”; колумб+im $\leftarrow$ Колумб “прізвище мореплавця Х. Колумба"; нагіаг $+i m \leftarrow$ Нагіаг “найменування родовища в Румуніі”; отен +im $\leftarrow$ Отен “назва міста у Франціі” тощо), рідше суфіксів -ин (андез $+u н \leftarrow$ Анди “найменування гір у Південній Америці"; сnесарт $+u н \leftarrow$ Спессарт (Шпессарт) “найменування родовища в Баварії"), -ін (корнеруn+iн $\leftarrow$ Корнеруп “прізвище датського геолога А. Н. Корнерупа"; $п е н+i н \leftarrow$ Пенніни (Пеннінські Альпи) “найменування гірських хребтів у Західних Альпах, Швейцарії та Італії”; сильв+ін $\leftarrow$ Сильвія “ім’я французького хіміка Сильвії де ля Баш”), -ан (нозе+ан $\leftarrow$ Нозе “прізвище французького мінералога К. В. Нозе”; обсидi+aн 
Обсидіус “ім’я римлянина, який привіз камінь із Ефіопії”), -ій (ванад+iй $\longleftarrow$ Ванадіс “ім'я давньоскандинавської богині краси”), -ар (адул+яр $\leftarrow$ Адула “назва родовища в горах Адула в Швейцарії').

У разі, коли твірна основа закінчується на голосний, формант -im згідно з чинними правописними нормами набуває відповідного оформлення (-їm). Наприклад: паско $+\ddot{i m} \leftarrow$ Паско “найменування департаменту в Перу”; танге+їm $\longleftarrow$ Танге “найменування ущелини у Ферганській долині”; хунчжао+їm Хун-Чжао “прізвище китайського мінералога Чжан Хун-Чжао”; чаo+ïm $\leftarrow$ Чао "прізвище американського метролога Е. Чао"; юрi+̈̈m $\leftarrow$ Юрі “прізвище американського дослідника Г. К. Юрі"; юта+їm Ł Юта "найменування штату у США”; яго $+\ddot{i m} \leftarrow$ Яго “прізвище американського колекціонера Д. Б. Яго"; ямато+їm $\leftarrow$ Ямато “найменування родовища в Японіі” тощо. Іноді такі відонімні деривати отримують незвичне для української мови графічне й орфоепічне оформлення, як-от: сакураї+їm $\leftarrow$ Сакураї “прізвище японського мінералогааматора К. Сакураї’.

Окрім того, деякі з відонімних дериватів спродукованой неморфологічними способами, як-от: каолін $\longleftarrow$ Каолін “найменування місцевості в Китаї” (пор.: номера стала дериваційною базою для продукування іншого деривата каолін $+i m)$; полукс $\leftarrow$ Поллукс “ім'я давньогрецького міфічного героя" (пор.: полуи +um - інша назва відповідного мінералу утворена морфологічним способом - засвідчує певні фономорфологічні процеси); халщедон $\leftarrow$ Халкедон “найменування давньогрецького міста, розташованого в Малій Азії; гент +гельвін $\leftarrow$ Гент “прізвище німецько-американського хіміка і мінералога Ф. А. Гента" та гельвін; ульв + о + шпінель $\leftarrow$ Норра-Ульве “найменування родовища в Швеції” та шпінель (пор.: ульв+im - інша назва відповідного мінералу утворена морфологічним способом); петербайліс $+u m \leftarrow$ Петер Байліс “ім'я та прізвище мінералога"; урал+бор $+u m \leftarrow$ Уральські “найменування гір” та бор тощо. Подекуди натрапляємо на зразки, коли різні деривати спродуковані на основі однієї і тієї ж дериваційної бази або, навпаки, на основі різної дериваційної 
бази утворені омонімічні одиниці. Наприклад, найменування мінералів бертьєр+uн та бертьєр+um спродуковані від антропоніма Бертьє “прізвище французького хіміка і геолога П’єра Бертьє”; для номінації мінералів ковел+ін і ковел+im послужило прізвищеве найменування італійського мінералога Н. Ковеллі; мос $+u m \leftarrow$ Моос "прізвище німецького мінералога та геолога К. Ф. Х. Мооса" та мос + um $\leftarrow$ Мосс “найменування родовища в Норвегіï'.

Низка дериватів містить у своїй структурі компонент літ (< грец. lithos - “камінь”) у функції суфіксоїда. Причому такий формант здебільшого не приєднується за допомогою сполучних голосних $o$ чи $e$, як це буває зазвичай у композитних утвореннях, а доданий до твірного слова загалом, наприклад: бендиліт $\leftarrow$ Бенді “прізвище першовідкривача М. Ч. Бенді"; iндріаліт $\longleftarrow$ Індрія “найменування родовища в колишній Югославії”; маріаліт Ł Маріа “ім’я дочки німецького мінералога Г. Розе”; осуміліт $\longleftarrow$ Осумі “найменування провінції в Японіi”; оямаліт Ł Ояма “найменування родовища в Японіі”; перииліт, персиліт $\leftarrow$ Перці “прізвище англійського металурга Дж. Перці"; сагамаліm $\leftarrow$ Сагама "прізвище фінського геохіміка Т. Сагами"; тугуаліт $\leftarrow$ Тухуа "найменування Нової Зеландії мовою маорі” (пор.: бендоліт, індріоліт, маріоліт, осумоліт, оямоліт, периоліт, персоліт, сагамоліт, тугуоліт). Іноді поява так званого сполучного голосного, очевидно, варто пояснювати хіба що за аналогією: даналіт $\leftarrow$ Дан “прізвище американського мінералога Е. С. Дана” (пор.: даноліт). Це, своєю чергою, спричиняє різні потрактування, зокрема, коли йдеться про дериваційну базу, що являє собою невідмінювані слова, які закінчуються на $о$, $e$, наприклад: йогачидоліт $\leftarrow$ Йохачідо “найменування місцевості в Північній Кореі”; омінеліт $\leftarrow$ Оміне “найменування гори в Японіï”; cacoлim $\longleftarrow$ Сассо “найменування родовища в Італіі”; manioлim $\leftarrow$ Тапіо “найменування бога лісу у фінській міфології”; цезароліт $\leftarrow$ Цезаро “прізвище бельгійського мінералога Г. Цезаро" тощо. Виникає слушне запитання: у таких зразках $о, e \epsilon$ інтерфіксом чи частиною твірного слова? 
Значна кількість гірничих термінів, зокрема на означення гірських порід чи мінералів, мають у своїй структурі формальний сегмент літ, який, вочевидь, жодного стосунку до відповідного суфіксоїда немає, оскільки такий елемент виник переважно внаслідок випадкового збігу - приєднання форманта -im до твірної основи, що закінчується на л. До того ж продукування того чи того деривата подекуди супроводжується й певними фономорфологічними процесами (усічення, чергування, суміщення, інтерфіксація і т. ін.), як-от: казоліт Казоло “найменування географічного регіону в Конго"; лонсдейліт $\leftarrow$ Лонсдейл “прізвище ірландського кристалографа К. Лонсдейл"; маріуполіт $\leftarrow$ Маріуполь “найменування міста в Україні”; сабугаліт $\longleftarrow$ Сабугал “найменування міста в Португаліі”; тагіліт $\leftarrow$ (Нижній) Тагіл “найменування міста в Росіі”; тремоліт $\leftarrow$ Тремола “найменування долини у Швейцаріі”; троїліт $\longleftarrow$ Троїлі “прізвище італійського священика Д. Троїлі”; ураліт $\leftarrow$ Урал “найменування географічного регіону в Росії”; фогліт $\leftarrow$ Фогль “прізвище німецького мінералога Й. Ф. Фогля”; ярліт $\leftarrow$ Ярл “прізвище датського дослідника і промисловця К. Ф. Ярла”.

Формальні зміни твірної основи у структурі похідної одиниці для термінології гірничої справи - явище непоодиноке. Зрідка натрапляємо на морфологічні чергування (закономірні чи то незакономірні), у результаті яких відбувається зміна фонологічного складу морфеми, наприклад: подоліт $\leftarrow$ Поділля “найменування неофіційної території в Україні”; києвіт $\leftarrow$ Київ “найменування столиці України”; вороб’єв+im $\leftarrow$ Воробйов “прізвище російського мінералога В. І. Воробйова" (пор. нормативно воровйовіт). Іноді морфонологічні модифікації спостерігаємо у твірній основі, коли іiі фінальний елемент пристосовується до початку наступної морфеми, як-от: англез+um $\leftarrow$ Англсі “найменування області у Великій Британіи”; марm+um $\longleftarrow$ Марс “найменування міфологічного бога війни"; мердоч+um $\leftarrow$ Мердок (Murdoch) "прізвище американського геолога Й. Мердока"; мозез+um $\longleftarrow$ Мозес (Moses) "прізвище американського мінералога А. Дж. Мозеса"; иой $+u m \leftarrow$ Цойс (Zois) “прізвище словенського збирача 
мінералів барона фон Цойса"; шрейберз+ит Ł Шрайберс “прізвище австрійського мінералога К. Шрайберса"; яроз+uт Яросо “найменування міжгір'я в Іспаніи” тощо.

При продукуванні досліджуваних термінів активно використовуваним $є$ явище усічення, при якому у процесі взаємопристосування морфем відбувається скорочення фіналі твірної основи. Інакше кажучи, твірна основа входить до деривата без надмірного кінцевого елемента, що складається 3 однієї або більше фонем, наприклад: авогадр $+u m \leftarrow$ Авогадро "прізвище італійського вченого, фізика, хіміка А. Авогадро"; андалуз+uт « Андалузія “найменування області в Іспаніi”; aнiв $+i m \leftarrow$ Анів’€ “найменування долини у Швейцарії”; бльод $+u m \leftarrow$ Бльоде “прізвище німецького хіміка К. Бльоде”; боле+їm $\leftarrow$ Болео “найменування родовища в Каліфорні1”; вiтер $+u m \leftarrow$ Візерінг (Withering) "прізвище британського ботаніка і лікаря В. Візерінга"; деклуаз+um $\leftarrow$ Деклуазо “прізвище французького мінералога А. Деклуазо”; долом+іm Доломіє "прізвище французького натураліста і геолога Д. Г. де Доломіє"; жедp+um $\leftarrow$ Жедре “найменування родовища у Франції”; ільмен $+i m \leftarrow$ Ільменські (гори) “найменування гір на Уралі"; ітабір + um $\longleftarrow$ Ітабірі "найменування родовища у Бразиліі”; клавер+um $\longleftarrow$ Клаверас “найменування округу в Каліфорнії; каледон+im $\leftarrow$ Каледонія “найменування місцевості в Шотландіï”; керчен $+i m \leftarrow$ Керченський (півострів) “найменування півострова у Криму”; копian+im $\longleftarrow$ Копіапо “найменування міста в Чилі”; котун+im $\leftarrow$ Котуньо “прізвище італійського фізика Д.Ф.А. Котуньо”; кюр $+u m \leftarrow$ Кюрі “прізвище фізиків П'єра та Марії Кюрі”; ларн+im $\longleftarrow$ Ларне “найменування родовища в Ірландіï”; лаутар $+u m \leftarrow$ Лаутаро “найменування округу в Чилі”; лінар+um $\leftarrow$ Лінарес “найменування міста в Іспаніï”; мурман+im $\leftarrow$ Мурманськ “найменування міста в Росії”; приазов+im $\leftarrow$ Приазов'я “найменування регіону в Україні”; тенор $+u m \leftarrow$ Теноре “прізвище італійського ботаніка М Теноре”; хуанх $+i m \leftarrow$ Хуанхе “найменування річки в Китаї”; шамоз+um $\longleftarrow$ Шамозон “найменування родовища у Швейцарії тощо. Як свідчить фактичний матеріал, найчастіше усіченню піддаються 
однокомпонентні кінцеві відрізки, що складаються з голосної фонеми $(o, e, i)$ або сполучення фонем (iнг, $a \kappa, i \epsilon, a c, e c, c b \kappa, о н$ i т. ін.). Причому фіналь $i$ піддавали усіченню лише тоді, коли до твірної основи додавали суфікс -ит. Використання суфікса -im у процесі приєднання його до дериватора, що у своїй структурі має фінальний сегмент $i$, ілюструє таке морфонологічне явище, як накладання, унаслідок чого на морфемному шві відбувається суміщення тотожних компонентів: вайрак $+i m \leftarrow$ Вайракі “найменування родовища в Новій Зеландіi”; вататсум $+i m \leftarrow$ Вататсумі “найменування японського бога моря"; гадолін $+i m \leftarrow$ Гадоліні “прізвище фінського хіміка і мінералога Й. Гадоліні"; тодорок+im Ł Тодорокі “найменування родовища в Японіï”.

Типовою для продукування термінів гірничої справи $€$ інтерфіксація - морфонологічне явище, при якому на морфемному шві з'являється асемантична прокладка, а саме: бертранд + um $\leftarrow$ Бертран (Bertrand) "прізвище французького мінералога Е. Бертрана"; бiom $+u m \leftarrow$ Біо "прізвище французького геодезиста Ж. Б. Біо”; вадал+im $\leftarrow$ Вада “прізвище першого генерального директора геологічної служби Японії Ц. Вада"; корнет +um $\leftarrow$ Корне "прізвище бельгійського геолога Ж. Корне"; кубан $+i m \leftarrow$ Куба “найменування острова в північній частині Карибського моря"; куке+їm $\leftarrow$ Кук (Cooke) "прізвище англійського першовідкривача і дослідника Дж. Кука"; леон $+i m \leftarrow$ Лео “ім’я німецького підприємця Лео Штріппельманна”; лемательєр+um $\leftarrow$ Ле Шательє (Le Chatelier) "прізвище французького хіміка Анрі Луї Ле Шательє"; мореноз+ит $\longleftarrow$ Морено “ім'я іспанського хіміка Антоніо Морено Руїса"; окарт+um $\leftarrow$ Окар “прізвище французького мінералога Р. Окара"; реньєр+um $\leftarrow$ Реньє "прізвище бельгійського геолога А. Реньє”; тарасовіт $\longleftarrow$ Тарас “ім'я українського письменника Т. Шевченка"; тенард + ит $\leftarrow$ Тенар “прізвище французького хіміка Л. Ж. Тенара"; фельшебані+їm $\leftarrow$ Фельшебаня “угорське найменування родовища Бая-Спріє в Румуні1”; часовр $+u m \leftarrow$ Часів Яр “найменування родовища на Донбасі” тощо. 
Міжморфемні сегменти виконують у проілюстрованих дериватах здебільшого чисто формальну функцію - спрощують процес поєднання морфем. Зазвичай інтерфікс мав би з'являтися тоді, коли на морфемному шві виникають сполучення фонем, що суперечать чинним морфонологічним нормам або нетипові для сучасної української мови. Однак насправді деякі з похідних одиниць спродуковані чи то за аналогією, чи то є недолугими кальками, зокрема i 3 російської мови, подекуди використовуються за традицією. Наприклад: ельба+їm - Ельба “найменування родовища 3 однойменною назвою острова в Середземномор'ї” (пор.: ельбіт); лозей+їm $\leftarrow$ Лозі “прізвище американського мінералога С.Р. Лозі” (пор.: лозит); осаризава+їm $\leftarrow$ Осаризава "найменування родовища в Японії" (пор.: осаризавіт); села+їm $\leftarrow$ Селла (Sella) “прізвище італійського мінералога К. Селли" (пор.: селит); щербина+їm Щербина "прізвище радянського геохіміка В. В. Щербини" (пор.: щербиніт) і т. ін. Непослідовність спостерігається й при продукування похідних на основі невідмінюваних дериваторів із фінальними сегментами $o, e, i$. У першому разі вони усікаються, в іншому - залишаються, спричиняючи появу асемантичної прокладки у вигляді фонеми $\breve{u}$, що в поєднанні з суфіксом -im графічно репрезентується як -їm, наприклад: піно $+\ddot{i m} \leftarrow$ Пінно “прізвище німецького геолога"; ренге+їm $\longleftarrow$ Ренге “найменування гори у префектурі Ніїгата"; унгарети+їm $\leftarrow$ Унгаретті “прізвище італійського вченого Л. Унгаретті”; фейгi+ïm $\leftarrow$ Фейгі “прізвище американського петрографа Дж. Фейгі"; шаурme+їm $\leftarrow$ Шаурте "прізвище німецького мінералога В. Т. Шаурте” (пор. ліказ+um $\leftarrow$ Ліказі “найменування копальні на території Конго”).

На думку науковців, саме інтерфікси допомагають уникнути так званого “затемнення” семантики похідного слова. Проте таке твердження $є$ не зовсім прийнятним для термінології гірничої справи, оскільки без довідкової енциклопедичної літератури іноді важко правильно встановити дериваційну базу, особливо коли маємо справу з іншомовною твірною основою. Це стосується не тільки дериваційних процесів, супроводжуваних тими чи тими фономорфологічними змінами, 
а й продукування досліджуваних найменувань загалом. 3 одного боку, частина дериватів дає змогу безпроблемно визначити дериваційну базу (алта+їm, алушт+ит, антарктик+im, астрахан+im, гагарін +im, донбас +um, карпат +uт, колумб+im, лермонтов +im, ломоносов+im, пржевальськ $+i m$ тощо), 3 іншого, - на основі асоціативних зв'язків установити дериватор, який, щоправда, не завжди матиме правильне потрактування $($ сремєєв $+i m \leftarrow$ Сремєєв (російський мінералог); йогансен $+i m \leftarrow$ Йогансен (американський петролог); макдональд+um Макдональд (американський геолог); ненадкевич+um Ненадкевич (учень В. І. Вернадського) тощо). До того ж на заваді десь-не десь стає й омонімія кореневих сегментів. Наприклад: ньютон $+i m \leftarrow$ Ньютон "найменування місцевості у США); матильд+um $\leftarrow$ Матильда "найменування родовища в Перу"; молдав $+i m \leftarrow$ Молдау “німецька назва річки Влтави”. Деякі 3 термінологічних номенів, згідно 3 довідковою літературою, не засвідчують жодного стосунку до того чи того оніма, від якого спродуковані, хоч у формальній структурі похідної одиниці виразно простежується передусім антропонімічна назва, як-от: адам+iн, валентин+im, валер+um, давид $+u m$, каӥн $+i m$ (останній пов'язують 3 нім. Kainit $<$ грец. kainos - “новий”) і т. ін. Установлення етимології цих та інших термінологічних найменувань потребує комплексного дослідження і зусиль науковців різних царин.

Ще одна проблема, яка потребує скрупульозного вивчення та розв'язання - нормалізація й уніфікація термінології гірничої справи. На сьогодні в гірничій термінологічній системі спостерігаємо відсутність єдиних підходів і щодо продукування тих чи тих термінів (вернадськіт / вернадськіїт), і щодо їх написання (пор.: любецььк+im $\leftarrow$ Любецький “прізвище польського князя Ф. Любецького"; матлок+im $\leftarrow$ Матлок “найменування міста в Англіі”; нев'янськ+im $\longleftarrow$ Нев'янськ “найменування міста в Росіі”; ольшанськ+im $\longleftarrow$ “прізвище радянського геохіміка Я. І. Ольшанського”; палигорськ $+i m \leftarrow$ Палигорськ “найменування станції на Уралі”; преображенськ $+i m \leftarrow$ Преображенський “прізвище радянського 
дослідника соляних родовищ П. І. Преображенського” але аляск + ит $\longleftarrow$ Аляска “найменування штату у США”).

Не сприяє стандартизації й нормалізації термінів гірничої справи ї їхня фонематична варіативність, пов'язана 3 проблемами українського правопису, передовсім із недосконалим правописом слів іншомовного походження. У розпорядженні науковців чимало варіантних термінологічних одиниць, що зумовлено різними причинами, 3-поміж яких вирізняється невміння передавати іншомовні оніми, зокрема й антропоніми, українською мовою.

У термінології гірничої справи наявна варіантність, зумовлена передаванням латинських графем $g$ i $h$ українською мовою. Згідно $з$ правилом такі іншомовні літери передаються зазвичай кириличною 2 [Ukrainskyi pravopys / Український правопис 2015:118] і лише “в окремих словах англійського походження $h$ передається літерою $x$ ” [Ukrainskyi pravopys / Український правопис 2015 : 119]. Натомість у термінологічній системі спостерігаємо непослідовність у написанні відповідних літер (ганіт, ленгенбахіт, леонгардтит, лонгбаніт, магнуссоніт, несквегоніт, нї̈гатаїт, трегерит і т. ін.), появу значної кількості варіантних дериватів, як-от: гейнрихіт, хейнрихіт; гринокіт, тринокіт; грюнерит, трюнерит; гумберстоніт, хумберстоніт; людвігіт, людвіпіт; люнебургіт, люнебургіт; пікерингіт, пікеринтіт; фаринттоніт, фарингтоніт; фройденбергіт, фройденбергіт і т. ін. На різнобій натрапляємо й при оформленні онімів-дериваторів: taнim $\leftarrow$ Ган “прізвище швецького хіміка Й. Г. Гана"; лентенбахіт $\leftarrow$ Ленгенбах “найменування родовища у Швейцарії”; леонгардтит Ł Леонгардт “прізвище німецького кристалографа Й. Леонгардта"; лонгбаніт $\leftarrow$ Лонгбан “найменування родовища у Швейцарії”; матнуссоніт $\longleftarrow$ Магнуссон "прізвище швецького геолога Н. Г. Магнуссона"; несквегоніт $\leftarrow$ Несквегонінг “найменування родовища у штаті Пенсільванія”; нї̈гатаїт $\leftarrow$ Ніїгата “найменування префектури на острові Хонсю в Японіі”; mрегерит $\leftarrow$ Tрегер "прізвище німецького гірничого інженера P. Трегера"; гейнрихіт, хейнрихіт (хейнричит, гейнричит) $\leftarrow$ Хейнріх “прізвище американського мінералога Е. В. Хейнріха”; 
гринокіт, тринокіт $\leftarrow$ Грінок “прізвище англійського лорда, який був власником землі, де цей мінерал було вперше знайдено"; грюнерит, трюнерит $\leftarrow$ Грюнер “прізвище французького геолога і металурга швейцарського походження Е. Л. Грюнера" гумберстоніт, хумберстоніт $\leftarrow$ Гамберстон “прізвище американського хіміка Дж. Т. Гамберстона"; людвігіт, людвігіт $\leftarrow$ Людвіг “прізвище австрійського хіміка Е. Людвіга"; люнебургіт, люнебургіт $\leftarrow$ Люнебург “найменування міста і родовища в Німеччині"; пікерингіт, nікерингіт $\leftarrow$ Пікерінг “прізвище американського дослідника Дж. Пікерінга"; фаринттоніт, фарингтоніт $\leftarrow$ Фаррінгтон “прізвище американського геолога О. Фаррінгтона"; фройденбергіт, фройденбергіт $\leftarrow$ Фройденберг “прізвище німецького геолога В. Фройденберга” тощо.

Відповідно до кодифікованих норм чинного українського правопису і дериватори і деривати, очевидно, повинні писатися або 3 літерою 2, або 3 літерою $\tau$, тобто терміни на позначення гірських порід та мінералів мали б мати таке оформлення: таніт, бо Gahn; леонгардтит, бо Leonhardt; матнуссоніт, бо Magnusson; mрегерит, бо Tröger; гейнрихіт, бо Heinrich; гумберстоніт, бо Humberston; пікеринтіт, бо Pickering; фаринттоніт, бо Farrington i т. ін. У цьому ж збірникові правописних законів наявне й твердження на зразок "У власних назвах іншомовного походження етимологічний $g$ згідно 3 усталеною традицією вимовляється як 2; проте збереження $g$ у вимові не є порушенням орфоепічної норми. Отже, правильною є вимова: Гданськ і Гданськ, Гренландія й Гренландія, Гібралтар і Гібралтар, Гарібальді й Гарібальді, Гете й Гете" [Ukrainskyi pravopys / Український правопис 2015 : 19]. Пор.: "У власних назвах іншомовного походження, які в мові-джерелі мають у своєму складі $g$, за новою орфоепічною нормою вимовляється [l]" [Suchasna ukrainska literaturna mova / Сучасна українська літературна мова 2002:80]. За таких підходів найменування, спродуковані на основі дериваторів, у структурі яких наявний $g$, повинні чи то всі мати паралельні варіанти, чи то єдиний варіант із літерою $\tau$, наприклад, людвітіт $\leftarrow$ Людвіг (Ludwig). Однак у тому ж правописі слово, що 
слугувало дериваційною базою, пропонують писати як Людвіг [Ukrainskyi pravopys / Український правопис 2015 : 90] (пор.: Людвіг ван Бетхдвен [Ukrainskyi pravopys / Український правопис 2015 : 136]. Проблема ускладнюється ще й тим, що довідкова література по-різному репрезентує одні й ті ж найменування. Наприклад: гетит і тетит [Velykyi tlumachnyi slovnyk / Великий тлумачний словник 2009:234, 270], де перший витлумачують як “мінерал класу оксидів і гідроксидів", другий - як “мінерал; жовто-бурі, темно-бурі або чорні кристали 3 алмазним блиском", хоч, по суті, відповідні найменування використовуються для позначення одного і того ж поняття; тетит і гьотит [Mala hirnycha entsyklopediia / Мала гірнича енциклопедія 2004 : 309 ], гетит і гьотит [Spysok mineraliv / Список мінералів], де другі варіанти засвідчують порушення правил написання українською мовою іншомовного буквосполучення ое (Goethe). Не спостерігаємо чіткості щодо написання літер 2 та $t$ і в обговорюваному проекті українського правопису. Пор.: “У прізвищах та іменах людей допускається передавання звука [g] двома способами: шляхом адаптації до звукового ладу української мови - буквою г (Васко да Гама, Вергілій, Габсбург, Гарсія, Гегель, Георг, Гете, Грегуар, Гонгадзе, Гуллівер) і шляхом імітації іншомовного [g] - буквою г (Васко да Гама, Вертілій, Габсбург, Гарсія, Гетель, Георг, Гете, Ірегуар, Гонгадзе, Гуллівер і т. ін.)" [Proekt / Проект 2018 : 127]. Самі ж автори енциклопедії гірничої справи висловлюють таку думку: "Певну складність становило розрізнення термінів 3 літерами $t$ та 2. Ми вважали за потрібне в термінах латинського походження, а також у термінах 3 німецької, англійської, французької мов здебільшого транслітерувати $g$ через $\tau$, а в термінах грецького походження - найчастіше через г. При цьому враховувалася традиція фарингального (гортанного) 2 в українській мові, <..>. Водночас в іноземних прізвищах літера $g$ передана через проривний $\tau$ : Гіббс, Галілей, Гальвані, Гаусс і т. ін. Ми вважаємо цілком виправданим вживання літери $\tau$ всередині або в кінці слів-термінів $<\ldots>$, а також усередині прізвищ: Атрікола" [Mala hirnycha entsyklopediia / Мала гірнича

(с) Ж. Колоїз, 2019. 
енциклопедія 2004 : 6]. Проте насправді таке твердження доволі часто порушується.

Термінологія гірничої справи рясніє зразками, які демонструють непослідовність i варіантність написання відонімних дериватів, спродукованих на основі власних назв, що ілюструють подвоєння. Згідно з чинним правописом подвоєння зберігається й у похідних одиницях [Ukrainskyi pravopys / Український правопис 2015 : 120]. Наприклад: ведделліт $\leftarrow$ Ведделла “найменування моря в Антарктиці"; віллем+im $\leftarrow$ Віллем "прізвище нідерландського короля"; волластон + im $\leftarrow$ Волластон "прізвище англійського дослідника В. Волластона"; гесc $+u m \leftarrow$ Гесс "прізвище російського фізика і хіміка Г. Гесса"; гіллебранд+um $\leftarrow$ Гіллебранд "прізвище американського хіміка Ф. Ю. Гіллебранда"; йоганн $+i m \leftarrow$ Йоганн “прізвище ерцгерцога Йоганна Австрійського"; кеммерер $+u m \leftarrow$ Каммерер “прізвище російського гірничого інженера О. Кеммерера"; ледгілл+im $\leftarrow$ Ледгіллс “найменування родовища в Шотландіi”. Причому подвоєння наявне в оригінальному написанні тих чи тих найменувань, переважно прізвищевих, як-от: лаубманн $+i m \leftarrow$ Лаубманн (Laubmann) “прізвище німецького мінералога Г. Лаубманна"; манассе+їm $\longleftarrow$ Манассе (Manasse) "прізвище італійського мінералога Е. Манассе”; монтичелл+іm $\leftarrow$ Монтічеллі (Monticelli) “прізвище італійського мінералога Т. Монтічеллі"; муассан $+i m \leftarrow$ Муассан (Moissan) "прізвище французького хіміка Ф.Ф.А. Муассана"; науманн $+i m \leftarrow$ Науманн (Naumann) “прізвище німецького мінералога К. Ф. Науманна". Попри те, що значна частина онімних дериваторів засвідчують подвоєння, відонімні деривати ілюструють його відсутність, наприклад: гейлюс $+u m \leftarrow$ ГейЛюссак "прізвище французького хіміка і фізика Ж. Л. ГейЛюссака"; гібc $+u m \leftarrow$ Гіббс "прізвище американського генерала Д. Гіббса"; Мічиганського університету Дж. Дорра"; карнал+іm $\leftarrow$ Карналла “прізвище прусського гірничого інженера Рудольфа фон Карналла"; кумінгтон $+i m \leftarrow$ Каммінгтон “найменування місцевості у штаті Массачусетс"; ліліан $+i m \leftarrow$ Лілліан “найменування родовища у штаті Колорадо”; ліне $+\ddot{i m} \leftarrow$ Лінней 
“ прізвище швейцарського ботаніка К. Ліннея”. Пор.: деривати без подвоєння 3 дериваційною базою та автентичним написанням твірної основи, грунтованим на латинській графіці : макелістер + um $\leftarrow$ Мак-Еллістер (McAllister) “прізвище американського геолога Дж. Ф. Мак-Еллістера"; мауф+im Ł Мауфф (Mauff) “прізвище родезійського геолога Г. Б. Мауффа”; меєргофер $+u m \leftarrow$ Мейєргоффер (Meyerhoffer) "прізвище німецького хіміка В. Мейєргоффера"; мілер $+u m \leftarrow$ Міллер (Miller) “прізвище англійського мінералога В. Міллера"; міліс +um $\leftarrow$ Мілліс (Millis) “прізвище американського дослідника Ф. Т. Мілліса"; тенант + иm $\leftarrow$ Теннант (Tennant) "прізвище англійського хіміка С. Теннанта"; торей+їm $\leftarrow$ Торрей (Torrey) “прізвище американського дослідника Дж. Торрея” тощо. Звідси, відповідно, можна констатувати: аналізовані деривати суперечать чинним правописним нормам української мови. Іноді подвоєння $є$ результатом фонетичної адаптації іншомовної лексеми на українському грунті, як-от: маккельві+їm $\leftarrow$ Мак-Кельві (McKelvey) "прізвище американського геолога В. Е. Мак-Кельві”; маккінстрі+їm $\leftarrow$ Мак-Кінстрі (McKinstry) “прізвище американського геолога Х. Е. Мак-Кінстрі” тощо.

Ще однією важливою проблемою, що стосується не лише термінології гірничої справи, є суперечність між написанням онімного дериватора й апелятивного деривата, пов'язаного із так званим правилом “дев'ятки” (у загальних назвах після приголосних $\partial, m, 3, c, u, ж(\partial ж), u, u, p$ перед наступним приголосним пишемо $u$ [Ukrainskyi pravopys / Український правопис 2015:122]), яке, як відомо, здебільшого не поширюється на власні назви. Звідси, відповідно, маємо відмінні щодо правопису кореневі морфеми (рідше - суфіксальні) у твірній основі й похідній одиниці, як-от: кристобаліт $\leftarrow$ СанКрістобаль (San Cristbal) "найменування місцевості в Мексиці"; морин $+i m \leftarrow$ Моріно (Morineau) “прізвище директора олов'яних шахт у Франції”; $р \boldsymbol{и} н к+i m \leftarrow$ Рінк (Rink) “прізвище датського промислового діяча Рінка"; рихтер+um $\leftarrow$ Ріхтер (Richter) “прізвище німецького хіміка Т. Ріхтера"; рокбридж+um $\leftarrow$ Рокбрідж (Rockbridge) “назва місцевості у штаті Вірджинія"; 
силіман +im $\leftarrow$ Сіллемен (Sillimen) "прізвище американського хіміка Б. Сіллімена"; симплот + um $\leftarrow$ Сімплот (Simplot) “прізвище американського власника рудника Дж. Р. Сімплота”; сингал+im $\leftarrow$ Сінхала (Sinhala) “санскритське найменування острова Шрі Ланка"; стилуел+im $\leftarrow$ Стіллуелл (Stillwell) “прізвище австралійського мінералога Ф. Дж. Стіллуелла"; mирел+im $\leftarrow$ Тіррелл (Tyrrell) “прізвище англійського геолога Д. У. Тіррелла"; циинвальд+um $\leftarrow$ Ціннвальд (Zinnwald) “найменування чеського родовища Ціновець німецькою мовою"; ичиле+ї $\leftarrow$ Ціппе (Zippe) “прізвище австрійського мінералога Ф. Ціппе”; шафариик+im $\leftarrow$ Шафарцік (Schafarzik) “прізвище угорського мінералога Ф. Шафарціка"; шеридан+im $\leftarrow$ Шерідан (Sheridan) “найменування родовища у штаті Вайомінг" тощо.

3 одного боку, науковці нібито виконують рекомендації правописної комісії (ідеться передусім про реалізацію правила “дев’ятки”), з іншого, - очевидним є вихід за межі традиційних фономорфологічних процесів, що супроводжують процес продукування похідної одиниці. Варто ще працювати над успішним розв'язанням проблеми, у результаті чого і відонімні деривати, й онімні дериватори писатимуться однаково. Деякі зразки ілюструють і інші орфографічні недоліки, наприклад, відсутність подвоєння в похідних одиницях, у твірних основах яких наявне таке подвоєння, наприклад: стилуел+im, тирел+im, цинвальд+um, циие +їm. Пор.: Стіллуелл (Stillwell), Тіррелл (Tyrrell), Ціннвальд (Zinnwald), Ціппе (Zippe), а тому, цілком закономірно, мали б утворитися такі похідні: стиллуелл+im, тиррел+іm, ииннвальд+um, ичиппе+їm. Окрім того, десь-не десь спостерігається неправильне написання й самої дериваційної бази: $p \boldsymbol{и} б е к+i m \leftarrow$ Ріббек (Ribbeck) “прізвище німецького дослідника Е. Ріббека"; тиман $+i m \leftarrow$ Тіманн (Tiemann) “прізвище німецького дослідника В. Тіманна" і т. ін. В енциклопедичній і довідковій літературі відповідні прізвищадериватори подані без подвоєння (пор.: рибек+im і риббек+im; тиман +im i тиманн+im). Або: канкрин $+i m \leftarrow$ Канкрин "прізвище російського державного діяча німецького походження Є. Ф. Канкрина” (але в жодному разі не Канкрін). 
Зрідка (усупереч правилу “дев’ ятки”) натрапляємо на написання літери $i$ на місці и, що знову ж таки дає підстави стверджувати про розхитування орфографічних норм: морімото+ї $\leftarrow$ Морімото (Morimoto) "прізвище японського мінералога Нобуо Морімото"; сімонс + um $\longleftarrow$ Сіммонс (Simmons) "прізвище професора мінералогії та петрології в Новоорлеанському університеті"(пор.: моримото+їт, моримот+ит; симмонс+ит). Іноді, навпаки, правило “дев'ятки” неправомірно поширюють на написання дериватів, утворених від українських відонімних найменувань: симфер $+u m \leftarrow$ Сімферополь “найменування міста у Криму”.

Чинний правопис не дає чіткої відповіді на питання, як слід передавати іншомовні букви чи то буквосполучення, зокрема $\ddot{o}, e u$, oе і т. ін., що спричинило появу низки варіантних термінів, непослідовність в оформленні відповідних похідних, наприклад: ремер+um, ромер+um, рьомер+um. Мінерал, для означення якого використовують проілюстровані терміни, отримав свою назву від прізвища німецького геолога Ф. А. Ремера, що в оригіналі звучить як Römer, де німецьке $\ddot{о}$ на українському грунті передається через $e$, а відтак дериваційна база в жодному разі не може бути представлена словом Рьомер. Звідси, відповідно, єдино правильний варіант: ремер+uт $\leftarrow$ Ремер (Römer). Пор.: шен $+i m \leftarrow$ Шене (Schöne) “прізвище німецького урядовця", шрекінгер + um $\leftarrow$ Шрекінгер (Schröekinger) "прізвище австрійського геолога і мінералога Й. фон Шрекінгера” (але аж ніяк не Шрьокінгер) тощо. Непослідовність позначення звуків, не властивих українській вимові, зумовлена різним написання іншомовних онімів у мовідонорі та в українській мові. До того ж певні модифікації спричинені впливом мови-посередника, зокрема російської.

Висновки та перспективи подалыших наукових розвідок. Обсяг запропонованої наукової праці не дає змоги зупинитися на абсолютно всіх дискусійних моментах. Гадаємо, окреслена проблема потребує подальшого дослідження, яке сприятиме всебічному лінгвістичному вивченню термінології гірничої справи, iï уніфікації й нормалізації, приведенню 
у відповідність із кодифікованими нормами українського правопису.

Наразі ж узагальнимо: скрупульозне дослідження апелятивних відонімних дериватів, що функціонують у термінологічному корпусі гірничої справи, має важливе значення для стандартизації української термінології загалом та гірничої зокрема. Недостатне опрацювання питання нормалізації й уніфікації призводить до появи так званих подвійних стандартів. Причому такі подвійні стандарти репрезентовані й лексикографічними працями, які дають право вибору, що подекуди є не завжди правильним. 3 лінгвістичних позицій заслуговує на увагу й виявлення генетичних особливостей термінів гірничої справи, а також адаптація іншомовних запозичень на українському грунті.

Продукування, написання та вживання гірничих апелятивних відонімних дериватів має відбуватися згідно 3 чинними нормами української мови (орфоепічними, орфографічними, словотвірними і т. ін.).

\section{Література}

1. Барабанова О., Колган О. Деякі аспекти деривації термінів гірництва. Вісник Національного у-ту “Львівська політехніка". 2010. № 675. С. 3-6.

2. Вакуленко М. О. Українська термінологія: комплексний лінгвістичний аналіз : монографія. Івано-Франківськ : Фоліант, 2015. 361 с.

3. Великий тлумачний словник сучасної української мови / уклад. і голов. ред. В. Т. Бусел. Київ-Ірпінь : ВТФ Перун, 2009. 1736 с.

4. Дзюба М. М. Епоніми в українській науковій термінології : автореф. дис. ... канд. філол. наук : 10.02.01 / Волинський національний ун-т ім. Лесі Українки. Луцьк, 2011. 20 с.

5. Дзюба М. Епонімічні найменування в українській науковій термінології. Українська мова. 2010. № 3. С. 55-63.

6. Дзюба М. Проблеми лексикографічного опрацювання епонімічних термінів. Вісник Національного ун-ту “Львівська політехніка". Серія “Проблеми української термінології”. Львів, 2012. № 733. С. 71-74.

7. Колган О. В. Семантична та словотвірна структура української гірничої термінології : автореф. дис... канд. філол. наук : 10.02.01 / Запорізький національний університет. Запоріжжя, 2009. 18 с.

8. Левченко М. Замітки про русинську термінологію. Основа. 1861. № 7. URL : http://litopys.org.ua/rizne/rusyny.htm

9. Лисенко В. І. Терміни-епоніми в українській анатомічній термінології // Вісник Національного університету “Львівська політехніка". Серія : Проблеми української термінології. Львів, 2009. № 648. С. 66-70. 
10. Мала гірнича енциклопедія : у 3-х т. / за ред. В. С. Білецького. Донецьк : Донбас, 2004. Т. 1. 640 с.

11. Мала гірнича енциклопедія : у 3-х т./ за ред. В. С. Білецького. Донецьк : Донбас, 2007. Т. 2. 652 с.

12. Мала гірнича енциклопедія : у 3-х т. / за ред. В. С. Білецького. Донецьк : Схід. видав. дім, 2013. Т. 3. 644 с.

13. Микульчик Р. Б. Прізвищеві та відпрізвищеві терміни в мові української фізичної термінної системи: особливості структури та функціювання : дис.... канд. філол. наук : 10.02.01 / Львівський національний ун-т імені Івана Франка. Львів, 2016. 258 с.

14. Овчаренко Н. I. Способи номінації і словотворення у сучасній українській мінералогічній термінології : дис....канд. філол. наук : 10.02.01 / Донецький державний ун-т. Донецьк, 1996. 218 с.

15. Панько Т. І., Кочан І. М., Мацюк Г. П. Українське термінознавство : підручник. Львів :Світ, 1994. 216 с.

16. Проект : Український правопис. URL : https://mon.gov.ua/storage/app/ media/gromadske-obgovorennya/2018/08/15/novoi-redaktsii-pravopisu.pdf

17. Сокол І. О. Основні віхи розвитку української гірничої термінології. Термінологічний вісник. 2013. Вип. 2 (2). С. 52-57.

18. Список мінералів. URL: https://uk.wikipedia.org/wiki

19. Сучасна українська літературна мова : підручник / за ред. А. П. Грищенка. 3-є вид., допов. Київ : Вища школа, 2002. 439 с.

20. Тлумачний гірничий словник / В. С. Білецький, К. Ф. Сапіцький, Б. С. Панов та ін. / під заг. ред. В. С. Білецького. Донецьк : ДДТУ, 1998. 446 с. URL : https://studfiles.net/preview/4494413/

21. Томіленко Л.М. Термінологічна лексика в сучасній тлумачній лексикографії української літературної мови : монографія. Івано-Франківськ : Фоліант, 2015. 160 c.

22. Український правопис. Київ : Наук. думка, 2015. 286 с.

\section{References}

1. Barabanova O., Kolhan O. Deiaki aspekty deryvatsii terminiv hirnytstva. Visnyk Natsionalnoho u-tu "Lvivska politekhnika”. 2010. № 675. S. 3-6.

2. Vakulenko M. O. Ukrainska terminolohiia: kompleksnyi linhvistychnyi analiz : monohrafiia. Ivano-Frankivsk : Foliant, 2015. $361 \mathrm{~s}$.

3. Velykyi tlumachnyi slovnyk suchasnoi ukrainskoi movy / uklad. i holov. red. V. T. Busel. Kyiv-Irpin : VTF Perun, 2009. 1736 s.

4. Dziuba M. M. Eponimy v ukrainskii naukovii terminolohii : avtoref. dys. ... kand. filol. nauk : 10.02.01 / Volynskyi natsionalnyi un-t im. Lesi Ukrainky. Lutsk, 2011. $20 \mathrm{~s}$.

5. Dziuba M. Eponimichni naimenuvannia v ukrainskii naukovii terminolohii. Ukrainska mova. 2010. № 3. S. 55-63.

6. Dziuba M. Problemy leksykohrafichnoho opratsiuvannia eponimichnykh terminiv. Visnyk Natsionalnoho un-tu "Lvivska politekhnika". Seriia "Problemy ukrainskoi terminolohii”. Lviv, 2012. № 733. S. 71-74. 
7. Kolhan O. V. Semantychna ta slovotvirna struktura ukrainskoi hirnychoi terminolohii : avtoref. dys... kand. filol. nauk : 10.02.01 / Zaporizkyi natsionalnyi universytet. Zaporizhzhia, 2009. $18 \mathrm{~s}$.

8. Levchenko M. Zamitky pro rusynsku terminolohiiu. Osnova. 1861. № 7. URL : http://litopys.org.ua/rizne/rusyny.htm

9. Lysenko V. I. Terminy-eponimy v ukrainskii anatomichnii terminolohii // Visnyk Natsionalnoho universytetu "Lvivska politekhnika". Seriia : Problemy ukrainskoi terminolohii. Lviv, 2009. № 648. S. 66-70.

10. Mala hirnycha entsyklopediia : u 3-kh t. / za red. V. S. Biletskoho. Donetsk : Donbas, 2004. T. $1.640 \mathrm{~s}$.

11. Mala hirnycha entsyklopediia : u 3-kh t./ za red. V. S. Biletskoho. Donetsk : Donbas, 2007. T. 2. $652 \mathrm{~s}$.

12. Mala hirnycha entsyklopediia : u 3-kh t. / za red. V. S. Biletskoho. Donetsk : Skhid. vydav. dim, 2013. T. 3. $644 \mathrm{~s}$.

13. Mykulchyk R. B. Prizvyshchevi ta vidprizvyshchevi terminy $\mathrm{v}$ movi ukrainskoi fizychnoi terminnoi systemy: osoblyvosti struktury ta funktsiiuvannia : dys... kand. filol. nauk : 10.02.01 / Lvivskyi natsionalnyi un-t imeni Ivana Franka. Lviv, 2016. $258 \mathrm{~s}$.

14. Ovcharenko N. I. Sposoby nominatsii i slovotvorennia u suchasnii ukrainskii mineralohichnii terminolohii : dys... kand. filol. nauk : 10.02.01 / Donetskyi derzhavnyi un-t. Donetsk, 1996. $218 \mathrm{~s}$.

15. Panko T. I., Kochan I. M., Matsiuk H. P. Ukrainske terminoznavstvo : pidruchnyk. Lviv :Svit, 1994. $216 \mathrm{~s}$.

16. Proekt : Ukrainskyi pravopys. URL : https://mon.gov.ua/storage/app/media/ gromadske-obgovorennya/2018/08/15/novoi-redaktsii-pravopisu.pdf

17. Sokol I. O. Osnovni vikhy rozvytku ukrainskoi hirnychoi terminolohii. Terminolohichnyi visnyk. 2013. Vyp. 2 (2). S. 52-57.

18. Spysok mineraliv. URL: https://uk. wikipedia.org/wiki

19. Suchasna ukrainska literaturna mova : pidruchnyk / za red. A. P. Hryshchenka. 3-ye vyd., dopov. Kyiv : Vyshcha shkola, 2002. $439 \mathrm{~s}$.

20. Tlumachnyi hirnychyi slovnyk / V. S. Biletskyi, K. F. Sapitskyi, B. S. Panov ta in. / pid zah. red. V. S. Biletskoho. Donetsk : DDTU, 1998. 446 s. URL : https://studfiles.net/preview/4494413/

21. Tomilenko L. M. Terminolohichna leksyka $\mathrm{v}$ suchasnii tlumachnii leksykohrafii ukrainskoi literaturnoi movy : monohrafiia. Ivano-Frankivsk : Foliant, 2015. $160 \mathrm{c}$.

22. Ukrainskyi pravopys. Kyiv : Nauk. dumka, 2015. 286 s.

Стаття надійшла до редакиії 10.01.2019 p. Прийнята до друку 07.05. 2019 p. 